\title{
PROBLEMATIKA YURIDIS PEMUNGUTAN BEA PEROLEHAN HAK ATAS TANAH DAN BANGUNAN DAN KETERKAITANNYA DENGAN FUNGSI PEJABAT PEMBUAT AKTA TANAH (STUDI DI KOTA MEDAN)
}

\author{
ASTRIANA SIANTURI \\ Program Studi Magister Kenotariatan \\ Fakultas Hukum Universitas Sumatera Utara \\ Jalan Dr. T. Mansur Nomor 9, Kampus Padang Bulan, Medan \\ Telp.(061)8211633, Email: astrianasianturi@gmail.com
}

\begin{abstract}
Tax plays a vital role in is the State's revenues since it contributes $70 \%$ of the State's revenues. The increase in the country's development has increased the availability of land and buildings although they are actually very limited. Therefore, it is appropriate if individuals and legal entities get economic values and land or buildings due to the State's BPHTB (Duty on Land and Building Right Acquisition). The research problems are how about the regulation on collecting BPHTB in Medan according to legal provisions, how about the role of PPAT (official empowered to draw up land deeds) concerning BPHTB, and how about the sanction imposed on PPAT and Taxpayers who have signed a deed which BPHTB has not yet paid off.
\end{abstract}

Keywords: BPHTB, PPAT, Land and Building Acquisition

\section{Intisari}

Pajak merupakan penerimaan negara yang paling besar sehingga pajak memiliki peran yang vital dalam sebuah negara. Di Indonesia pajak merupakan salah satu penopang pendapatan nasional yang menyumbangkan lebih kurang $70 \%$ dari penerimaan negara. Meningkatnya kegiatan pembangunan di segala bidang mengakibatan meningkatknya keperluan akan tersedianya tanah dan bangunan, sedangkan tanah dan atau bangunan persediaannya terbatas, maka sudah sewajarnya orang pribadi atau badan hukum yang memperoleh nilai ekonomis serta manfaat dari tanah atau bangunan karena perolehan hak atas tanah dan bangunan dikenakan pajak oleh negara. Pajak yang dimaksud adalah Bea Perolehan Hak atas Tanah dan /atau Bangunan (BPHTB). Berdasarkan hal-hal tersebut diatas maka permasalahan-permasalahan yang akan diteliti dalam penelitian ini yaitu: Bagaimana Pengaturan hukum tentang pemungutan Bea Perolehan Hak Atas Tanah dan Bangunan (BPHTB) di Kota Medan menurut peraturan perundang undangan ? Bagaiamana peranan Pejabat Pembuat Akta Tanah dalam kaitannya dengan Bea Perolehan Hak Atas Tanah dan/atau Bangunan (BPHTB? Bagaimana ketentuan sanksi yang diberikan terhadap 
penandatanganan akta yang belum dibayarkan BPHTB yang dilakukan oleh PPAT dan Wajib Pajak.

Kata kunci: Bea Perolehan Hak atas Tanah/dan atau Bangunan (BPHTB),Pejabat Pembuat Akta Tanah ( PPAT), Perolehan Hak atas tanah dan bangunan 


\section{A. Latar Belakang}

Penggolongan pajak berdasarkan lembaga pemungutannya di Indonesia dapat dibedakan menjadi 2 (dua) yaitu Pajak Pusat dan Pajak Daerah. Pajak Pusat adalah pajak-pajak yang dikelola oleh Pemerintah Pusat dal hal ini sebagian besar dikelolah oleh Direktorat Jenderal Pajak Kementrian Keuangan. Pajak Pusat terdiri dari Pajak Penghasilan (PPh), Pajak Pertambahan Nilai (PPN), Pajak Penjualan Atas Barang Mewah (PPnBM), Pajak Bumi dan Bangunan (PBB), Pajka Bumi dan Bangunan Perkebunan, Perhutanan dan Pertambangan (PBB P3), Bea Materai,dan Penerimaan Negara yang berasal dari Migas. ${ }^{1}$

Pajak provinsi terdiri atas: Pajak Kendaraan Bermotor,Bea Balik Nama Kendaraan Bermotor,Pajak Bahan Bakar Kendaran Bermotor, Pajak Air Permukan; dan Pajak rokok; Jenis pajak Kabupten/kota terdiri atas:Pajak Hotel;Pajak restoran;Pajak Hiburan;Pajak Reklame;Pajak penerangan jalan;Pajak Mineral Bukan Logam dan Batuan;Pajak Parkir;Pajak air tanah;Pajak Sarang Burung Walet;Pajak Bumi dan Bangunan Pedesaan dan Perkotaan; dan Bea Perolehan Hak Atas Tanah dan

\footnotetext{
Siti Kurnia Rahayu, Perpajakan Indonesia Konsep dan Aspek Formal, Graha Ilmu Yogyakarta, 2010, hal 45
}

Bangunan; ${ }^{2}$ Tarif Bea Perolehan Hak atas Tanah dan Bangunan ditetapkan sebesar $5 \%$ (lima persaen. ${ }^{3}$ dan besarnya Nilai Perolehan Objek Pajak Tidak Kena Pajak ditetapkan sebesar Rp. 60.000.000,00 (enam puluh juta rupiah) untuk setiap wajib pajak . ${ }^{4}$

Wajib pajak menghitung sendiri objek pajak BPHTB sesuai dengan dasar pengenaan pajak yang telah ditentukan oleh ketentuan pajak dan membayar sendiri BPHTB dengan Surat Setoran Pajak Daerah (SSPD), tata cara penghitungan ini merupakan sistem perhitungan self assessment system. $^{5}$ Sistem pemungutan BPHTB ini diatur dalam Undang undang nomor 28 Tahun 2009 Pasal 98 juncto peraturan pemerintah nomor 91 tahun 2010.

Pejabat Pembuat Akta Tanah selanjutnya disebut PPAT adalah pejabat umum yang diberi kewenangan untuk membuat akta akta otentik mengenai perbuatan hukum tertentu mengenai Hak Atas Tanah dan Hak Milik Atas Satuan

${ }^{2}$ Pasal 2 Ayat (1) dan (2) Undang undang nomor 28 Tahun 2009 tentang Pajak Daerah dan Rertribusi Daerah

${ }^{3}$ Pasal 5 Peraturan Daerah Kota Medan Nomor 1 Tahun 2011 tentang Bea Perolehan Hak Atas tanah dan Bangunan

4 Pasal 4 Ayat (7) Daerah Kota Medan Nomor 1 Tahun 2011 tentang Bea Perolehan Hak Atas tanah dan Bangunan

${ }^{5}$ Panca Kurniawan dan Agus Purwanto, Pajak Daerah dan Retribusi Daerah Di Indonesia, Bayumedia Publishing, Malang, 2004, hal 126-127 
Rumah susun, PPAT ada 3 jenis antara lain: PPAT Biasa, PPAT Sementara, dan PPAT Khusus, ${ }^{6}$

Dasar yuridis Pemungutan BPHTB terdapat dalam Undang undang nomor 28 Tahun 2009 tentang Pajak Daerah Dan Retribusi Daerah, telah mengatur dengan jelas bahwa untuk dapat dipungut pada suatu daerah, setiap jenis pajak daerah harus ditetapkan dengan peraturan daerah Kabupaten/Kota dipungut pada suatu daerah kabupaten, atau kota harus terlebih dahulu ditetapkan peraturan daerah tentang pajak daerah tersebut. $^{7}$

Sehubungan dengan Bea Perolehan Hak Atas Tanah Bangunan (BPHTB) maka terbitlah Undang undang nomor 20 Tahun 2000 Tentang Perubahan atas Undang Undang nomor 21 Tahun 1997 tentang Bea Perolehan Hak Atas Tanah dan Bangunan, pengalihan pengelolaan Bea Perolehan Hak Atas Tanah Bangunan (BPHTB) dari pemerintah Pusat ke pemerintah Dearah sesuai amanat Undang undang Nomor 28 Tahun 2009 tentang Pajak Daerah dan Retribusi Daerah, maka pemerintah Kota Medan menerbitkan sejumlah Peraturan Daerah (Perda) yaitu Perda Nomor 1

${ }^{6}$ Peraturan Pemerintah Nomor 24 Tahun 2016 ayat (1) angka 1,2,3 tentang Pejabat Pembuat Akta Tanah.

${ }^{7}$ Rochman Soemitro, Dasar dasar Hukum Pajak dan Pajak Pendapatan, PT. Eresco,Jakarta, 1997, hal 1
Tahun 2011 tentang Bea Perolehan Hak Atas Tanah dan Bangunan dan Peraturan Bupati/Peraturan Walikota adalah Peraturan Walikota Medan Nomor 24 Tahun 2011 tentang Sistem dan Prosedur Pemungutan Perolehan Hak Atas Tanah dan Bangunan,

\section{B. Rumusan Masalah}

1. Bagaimana Pengaturan hukum tentang pemungutan Bea Perolehan Hak Atas Tanah dan Bangunan (BPHTB) di Kota Medan menurut peraturan perundang undangan ?

2. Bagaiamana peranan Pejabat Pembuat Akta Tanah dalam kaitannya dengan Bea Perolehan Hak Atas Tanah dan/atau Bangunan (BPHTB?

3. Bagaimana ketentuan sanksi yang diberikan terhadap penandatanganan akta yang belum dibayarkan BPHTB yang dilakukan oleh PPAT dan Wajib Pajak.?

\section{Metodologi Penelitian}

Penelitian ini bersifat analisis deskriptif. Jenis penelitian ini adalah jenis penelitian Yuridis noramtif .Sumber data yang digunakan dalam penelitian ini digunakan sebagai dasar untuk menunjang hasil penelitian adalah: ${ }^{8}$ sumber data sekunder terdiri dari,

a. Bahan hukum Primer, yaitu:

\footnotetext{
${ }^{8}$ Jhonny Ibrahim, Teori dan Metodologi Penelitian Hukum Normatif, Bayu Media Publishing, Malang, 2008, hal 25-26
} 
1. Undang- undang Dasar 1945;

2. Undang undang Nomor 28 Tahun 2009 tentnag Pajak Daerah dan Retribusi Daerah,

3. Peraturan Daerah Kota Medan Nomor 1 Tahun 2011 Tentang Bea Perolehan Hak atas Tanah dan Bangunan;

4. Peraturan Walikota Medan Nomor 24 Tahun 2011; dan

5. Undang undang nomor 20 Tahun 2000 Tentang Perubahan Atas Undang-Undang Nomor 21 Tahun 1997 Tentang Bea Perolehan Hak Atas Tanah dan Bangunan Pemungutan Pajak Daerah

6. Peraturan Pemerintah Nomor 55 Tahun 2016 Tentang Ketentuan Umum dan Tata Cara pemungutan pajak daerah,

b. Bahan Hukum Sekunder yakni Bahan yang memiliki hubungan yang erat dengan bahan hukum primer, seperti hasil penelitian, hasil seminar, hasil karya tulis, dokumen dan buku-buku yang terkait dengan penelitian.

c. Bahan Hukum Tertier merupakan bahan yang memberikan informasi hukum primer dan bahan hukum sekunder seperti kamus hukum, artikel, majalah, tabloid, surat kabar, dan studi terhadap semua dokumen yang berkaitan terhadap dokumen penelitian.
Teknik pengumpulan data (bahan hukum) dalam penelitian ini dilakukan dengan cara penelitian kepustakaan (library research) yang digunakan untuk memperoleh data dengan membaca, mempelajari, meneliti, mengidentifikasi dan menganalisis bahan hukum primer, sekunder maupun tersier.

Untuk pendukung data sekunder yang diperoleh dalam penelitian ini akan dilengkapi dengan data primer dalam bentuk wawancara langsung dengan beberapa informan yang terdiri dari 1 (satu) orang Pegawai Badan Pertanahan kota Medan, dan 1(satu) orang Pegawai kantor Kecamatan dan 2 (dua) orang Notaris /PPAT yang ada di Medan berkaitan dengan Problematika Yuridis Pemungutan Bea Perolehan Hak Atas Tanah dan Bangunan dan keterkaitannya dengan Fungsi Pejabat Pembuat Akta Tanah (Studi Di Kota Medan)

\section{Hasil Penelitian dan Pembahasan}

Bea Perolehan Hak Atsa Tanah danBangunanan sebagai salah satu penerimaan dalam Pendapatan Asli Daerah Kota Medan memberikan kontribusi dalam mendukung pertumbuhan ekonomi kota Medan untuk dapat melaksankan pembangunan yang berkelanjutan. Undang.-Undang Nomor 28 Tahun 2009 Tentang Pajak Daerah dan Retribusi 
Daerah telah mengatur bahwa Bea Perolehan Hak Atas Tanah dan Bangunan merupakan Pajak Daerah, sehingga untuk kota Medan telah diatur dalam Peratuan Daerah Kota Medan Nmor 1 Tahun 2011 Tentang Bea Perolehan Hak Atas Tanah dan Bangunan

\section{Sitem Pemungutan Pajak}

Sistem pemungutan pajak adalah suatu cara yang dilakukan guna untuk mengetahui dengan menghitung berapa besar pajak yang dibayarkan oleh seseorang terhadap negara yang ditempati, penjelasan tersebut mengacu pada sistem perpajakan yang dapat dikatakan sebagai metode pengelolaan utang pajak yang dibayarkan oleh yang bersangkutan agar dapat masuk ke kas negara. ${ }^{9}$

Sistem Pemungutan Pajak Pemungutan pajak yang dikenal 3 (tiga) sistem yaitu :

\section{1) Official Assesssment System:}

. Di dalam sistem ini petugas pajak yang sepenuhnya memiliki inisiatif dalam kegiatan menghitung dan juga pemungutan pajak. Penerapan pada sistem inipun ditujukan pada masyarakat selaku wajib pajak dilihat belum mampu untuk diberikan tanggungjawab dalam menghitung serta menetapkan pajak. Dan sistem ini akan berhasil apabila petugas

${ }^{9}$ Diakses dari https://www. Pajak.go.id. sistem perpajakan pada tanggal 1 November 2019 pukul 11.10 WIB. pajak secara integritas, kualitas, dan kuantitas sudah memenuhi kebutuhan dan standar yang ditetapkan

Adapun ciri-ciri sistem pemungutan pajak yang terdapat pada official assessment system ini adalah

a. Pajak yag dibayarkan dihitung dan ditentukan oleh petugas pajak (fiskus) yang dipilih dalam pengelolaan pajak,

b. Pihak yang membayar wajib pajak bersifat pasif, hanya akan memberikan perihal laporan pajak tersebut tetapi tidak menghitung penghasilannya dalam setahun,

c. Setelah petugas pajak (fiskus) menghitung dan menetapkan pajak yang harus dibayarkan, maka hutang pajak akan timbul dan petugas pajak mengeluarkan surat ketetapan pada pajak,

contoh pajak yang masih menerapkan sistem ini adalah Pajak Bumi dan Bangunan dan Pajak Daerah.

2) Self Assessment System

Sistem ini merupakan pemungutan pajak dimana wajib pajak (yang membayar pajak) diberikan kepercayaan untuk memenuhi kewajiban pajaknya, dimulai dari mendaftarkan wajib pajak, menghitung pajak,menyetorkan serta melaporkan pajak yang akan dibayarkan. 
Terdapat 3 (tiga) ciri-ciri dalam sistem pemungutan pajak ini:

a. Besar pajak yang dibayarkan dihitung dan ditentukan oleh wajib pajak,

b. Dalam memenuhi kewajiban pajaknya, wajib pajak bersifat aktif dimana mulai dari menghitung, melaporkan dan membayar pajak yang harus dibayar,

c. sistem ini, surat ketetapan pajak tidak selalu dikeluarkan oleh petugas pajak (fiskus) kecuali terdapat beberapa kasus tertentu seperti adanya keterlambatan dalam melapor dan membayar pajak,

Kelemahan yang terdapat dalam sistem ini yaitu pajak yang harus dibayarkan pada negara akan dihitung sekecil kecilnaya oleh wajib pajak. Sistem ini berlaku diindonesia terhitung dari tahun 1983, tepatnya setelah reformasi dan sampai sekarang. Walaupun tidak mutlak di Indonesia menganut sistem self assessment pada prinsipnya.

Ciri dan corak tersendiri dari sistem pemungutan pajak tersebut adalah:

a) Bahwa pemungutan pajak merupakan perwujudan dari pengabdian kewajibandan peran serta Wajib Pajak untuk secara langsung dan bersamasamamelaksanakan kewajiban perpajakan yang diperlukan untuk pembiayaannegara dan pembangunan nasional b) Tanggung jawab atas kewajiban pelaksanaan pajak, sebagai pencerminankewajiban di bidang perpajakan berada pada anggota masyarakat Wajib Pajaksendiri. Pemerintah, dalam hal ini aparat perpajakan sesuai dengan fungsinyaberkewajiban melakukan pembinaan, penelitian, dan pengawasan terhadappelaksanaan kewajiban perpajakan Wajib Pajak berdasarkan ketentuan yangdigariskan dalam peraturan perundang-undangan perpajakan;

c) Anggota masyarakat WajibPajak diberi kepercayaan untuk dapat melaksanakan kegotongroyongan nasional melalui sistem menghitung,memperhitungkan, dan membayar sendiri pajak yang terutang (Self Assessment), sehingga melalui sistem ini pelaksanaan administrasi perpajakan diharapkan dapat dilaksanakan dengan lebih rapi, terkendali, sederhana dan mudah untuk dipahami oleh anggota masyarakat Wajib Pajak. ${ }^{10}$

Contoh pajak yang menerapkan sistem ini yaitu besarnya pajak yang baru dikeluarkan seperti PPN, PPnBM, dan

\footnotetext{
${ }^{10}$ Meninjau-sistem-pemungutanpajak,http://indonesiantaxation.blogspot.com/2009/ 11/diakses tgl 9 Juli 2014
} 
PPh, termasuk Pajak Bea Perolehan Hak Atas tanah dan Bangunan (BPHTB)

\section{3) Withholding system}

Ciri dari withholding sytem yaitu pihak ketiga memiliki wewenang dalam menentukan berapa besar pajak yang harus dibayarkan, pihak yang dimaksudkan selain wajib pajak dan petugas pajak (fiskus) . Adapun keunggulan withholding system yaitu dengan adanya pihak ketiga yang menentukan besar pajak yang harus dibayarkan, yang bersangkutan tidak lagi perlu menghitung dan menyetorkan pajak yang akan diabayar, tetapi ada kelemahan dari sistem ini yaitu pihak ketiga bisa saja menggunakan uang pajak yang sudah dipungut dan tidak menyetorkannya.

\section{Prosedur Penagihan BPHTB} Menurut Perwal Kota Medan Nomor 24

Tahun 2011 tentang Sistem dan Prosedur Pemungutan BPHTB

Prosedur dan Penetapan surat Tagihan Pajak Daerah BPHTB merupakan proses yang dilakukan fungsi pelayanan dalam menetapkan tagihan BPHTB yang terutang yang disebabkan karena BPHTB terutang menurut SSPD BPHTB, tidak/kurang bayar, salah tulis, salah hitung dan bunga/denda. ${ }^{11}$ Prosedur ini melibatkan fungsi pelayanan sebagai pihak

11 Penjelasan Perwal No 24 Tahun 2011 tentang Sistem Pemungutan dan Prosedur Pemungutan Bea Perolehan Hak Atas Tanah dan Bangunan yang mwmiliki dan mengelola Database daftar Surat Tagihan Pajak Daerah (STPD) BPHTB, Daftar SKPD Kurang Bayar BPHTB, Daftar SKPD Kurang Bayar Tambahan BPHTB dan Daftar Surat Teguran.

a. Wajib Pajak :Merupakan pihak yang memiliki kewajiban membayar BPHTB terutang berdasarkan surat tagihan pajak daerah (STPD BPHTB, Surat Keputusan Pajak Daerah Kurang Bayar Tambahan BPHTB, Wajib pajak akan menerima surat teguran jika pada saat jatuh tempo belum melunasi BPHTB terutang,

b. Fungsi Pelayanan Merupakan pihak yang berwenang dan bertugas untuk: Memeriksa SSPD BPHTB, Menerbitksn STPD BPHTB, Menerbitkan SKPD kurang Bayar, Menerbitkan Kurang Bayar Tambahan .

\section{Tata Cara Pengurusan Akta} Pemindahan Hak Atas Tanah dan Atau Bangunan Menurut Perwal Nomor 24 Tahun 2011 tentang Sistem dan Prosedur Pemungutan BPHTB

Prosedur Pengurusan akta pemindahan hak atas tanah dan/atau bangunan merupakan proses pengajuan pembuatan akta sebagai dokumen legal 
penerimaan hak atas tanah dan/atau bangunan yang dilakukan oleh wajib pajak selaku penerima hak atas tanah dan atau/ bangunan kepada Pejabat Pembuat Akta Tanah. Prosedur ini melibatkan Pejabat Pembuat Akta Tanah sebagai pihak yang menyiapkan form SSPD BPHTB dan data Kata Pemindahan hak Atas Tanah dan/atau Bangunan. Dalam prosedur ini Pejabat Pejabat Pembuat Akta Tanah akan memeriksa kebenaran dan kelengkapan dokumen terkait pemindahan hak atas tanah dan/atau bangunan. Pemerikasaan dilakukan dengan mengecek dokumen dan data terkait objek pajak di Kepala Kantor Bidang PErtanahan.

Adapun Pihak terlibat adalah

a. Wajib pajak selaku penerima hak: Merupkan pihak yang memiliki kewajiban membayar BPHTB atas tanah dan da/atau bangunan yang diperolehnya. Dalam prosedur ini Wajib Pajak menyiapkan dan menyerahkan dokumen pendukung terkait pemindahan hak/atau bangunan.

b. Satuan Kerja Pengelola Keuangan Daerah (SKPKD) Merupakan pihak yang mempunyai otoritas dalam pengelolaan keuangan daerah, yang secara organisasi dapat berbentuk Dinas Pendapatan, Pengelolaan
Keuangan dan Asset Daerah (DPPKAD). Dalam prosedur ini, DPPKAD berkoordinasi dan bekerjasama dengan PPAT dalam menyiapkan Surat Setoran Pajak Daerah BPHTB

c. Pejabat Pembuat akta Tanah, Merupakan pihak yang membantu wajib pajak dalam menghitung BPHTB terutang dan menyiapkan SSPD BPHTB, pihak yang dapat menjadi PPAT adalah Camat atau Notaris. Dalam prosedur ini PPAT bertugas dan berwenang untuk :

1. Memeriksa kebenaran data terkait objek pajak ke kepala Kantor Bidang Pertanahan,

2. Menyiapkan draft akta Pemindahan Hak atas tanah dan/atau bangunan.

c. Kepala Kantor Bidang Pertanahan Merupakan pihak yang mengelola database pertanahan di wilayah wewenangnya . dalam prosedur ini kepala kantor bidang pertanahan menyediakan data yang dibutuhkan PPAT terkait pemeriksaan objek pajak.

\section{Hambatan Dalam Penetapan BPHTB Menurut Pendapat Notaris /PPAT}

$\begin{array}{rlll}\text { Verifikasi } & \text { atas } & \text { NPOP } & \text { yang } \\ \text { tercantum dalam } & \text { surat } & \text { setoran } & \text { pajak }\end{array}$


daerah BPHTB dapat menyebabkan harga transaksi yang disepakati oleh para pihak dikoreksi oleh Satuan Kerja Pengelola Keuangan Daerah kota Medan selaku aparatur pajak, akan tetapi proses koreksi yang dilakukan oleh petugas tersebut tidak menggunakan surat ketetapan pajak sebagai bentuk representasinya. Pihak Satuan Kerja Pengelola Keuangan Daerah selaku aparatur pajak dalam hal ini verifikasi tersebut secara de facto dapat manganulir kesepakatan harga antara para pihak. Kedudukan SKPKP dalam hal ini dikatakan pihak yang mempunyai kepentingan proses jual beli tersebut.

Pemungutan pajak secara umum sering kali terjadi kendala atau hambatan antara lain:

1. Peraturan pelaksana undang undang yang tidak konsisten dengan undang undangnya,

2. Kurangnya pembinaan antara pajak daerah dan nasional,

3. Database yang masih jauh dri standart,

4. Lemahnya penegakan hukum terhadap kepatuhan membayar pajak bagi penyelenggara pajak.

Proses verifikasi disinilah yang memerlukan waktu tidak singkat sehingga menghambat dan merugikan para pihak dan satu hal yang paling fatal apabila salah satu pihak meninggal dunia dan belum menandatangani akta tersebut dan kemudian ahli waris tidak sepakat dengan harga lama.

1. Kendala yang berhubungan dengan Wajib Pajak

Kendala pertama yakni kendala yang berhubungan wajib pajak lebih disebabkan oleh kurangnya pengetahuan masyarakat tentang pajak BPHTB dan kurangnya kesadaran dari masyarakat untuk membayar pajak BPHTB, sehingga wajib pajak mengalami kendala/kesulitan dalam melakukan perhitungan terhadap pajak BPHTB yang harus diabayrnya atas peralihan hak yang dilakukannya. Ditambah dengan adanya self assessment sistem dimana wajib pajak diberikan kewenangan untuk menghitung dan membayar sendiri jumlah pajak BPHTB yang harus dibayarnya. Dan juga petugas pajak mengalami kesulitan dalam hal pemungutan pajak karena kurangnya kesadaran masyarakat, juga adanya keterlambatan dalam pembayaran sehingga jatuh tempo pembayaran telah melewati batas pembayaran dan menimbulkan denda.

2. Kendala yang berhubungan dengan Sumber Daya Manusia

Kendala yang berhubungan dengan Sumber daya Manusia adalah masih 
kurangnya sumber daya manusia yang handal di bidang perpajakan BPHTB.

\section{Pengertian Pejabat Pembuat Akta Tanah}

Pasal 1 Peraturan Pemerintah Nomor 37 Tahun 1998 tentang Peraturan Jabatan PPAT menjelaskan pengertian PPAT adalah pejabat umum yang diberi kewenangan untuk membuat akta-akta otentik mengenai hak atas tanah dan hak milik atas satuan rumah susun. Menurut A.P. Parlindungan PPAT adalah pejabat umum yang diangkat pemerintah tetapi tidak digaji oleh pemerintah dan mempunyai kekuasaan umum artinya akta akta yang diterbitkan merupakan akta-akta otentik. $^{12}$

Mengingat pentingnya fungsi dan tugas Pejabat Pembuat Akta Tanah dalam kehidupan masyarakat di Indonesia sekarang ini maka pemerintah menetapkan juga kriteria-kriteria dan syarat-syarat dari Pejabat Pembuat Akta Tanah. Syarat untuk dapat diangkat menjadi PPAT adalah ${ }^{13}$

- Berkewarganegaraan Indonesia,

- Berusia sekurang kurangnya 30 Tahun
- Berkelakuan baik dan dinyatakan dengan surat keterangan yang dibuat oleh instansi kepolisian setempat,

- Belum pernah dihukum penjara karena melakukan kejahatan berdasarkan keputusan pengadilan yang memperoleh kekuatan hukum tetap,

- Sehat jasmani dan rohani,

- Lulus program pendidikan spesialis notaris dan program pendidikan khusus pejabat pembuat akta tanah diselenggarakan oleh lembaga pendidikan tinggi,

- Lulus ujian yang diselenggarakan oleh Kantor Menteri Agraria/Kepala Badan Pertanhan Nasional, sedangkan untuk melayani masyarakat dalam pembuatan akta dimana PPAT tersebut belum cukup terdapat PPAT Menteri dapat menunjuk PPAT sementara, dan PPAT Khusus. Pejabat yang menjadi PPAT Sementara ini adalah Camat atau Kepala desa di wilayah tersebut untuk melayani pembuatan akta.

6. Macam-Macam Pejabat Pembuat Akta Tanah dan Wilayah Kerja Pejabat Pembuat Akta Tanah

Menurut Peraturan Pemerintah Nomor 37 tahun 1998 tentang Pejabat

\footnotetext{
${ }^{12}$ A.P Parlindungan, Bunga Rampai Hukum Agraria serta Landreform, Bandung, 1989, bagian I, Hal. 131

${ }^{13}$ Pasal 6 Peraturan Pemerintah nomor 37 Tahun 1998 tentang Pejabat Pembuat Akta Tanah
} 
Pembuat Akta Tanah diatur mengenai 3 (tiga) macam PPAT, yaitu: ${ }^{14}$

a. PPAT selaku pejabat umum yang diangkat dan diberhentikan oleh Menteri/Kepala Badan Pertanahan Nasional dengan daerah kerja kota atau kabupaten,

b. Pejabat Pembuat Akta Tanah Sementara

Pejabat pembuat Akta Tanah Sementara (PPAT Sementara) adalah Pejabat Pemerintah yang ditunjuk karena jabatannya untuk melaksanakan tugas Pejabat Pembuat Akta Tanah (PPAT) dengan membuat akta PPAT didaerah yang belum cukup terdapat Pejabat Pembuat Akta Tanah (PPAT) (Pasal 1 angka 2 Peraturan Pemerintah Nomor 37 Tahun 1998 Tentang Pejabat Pembuat Akta Tanah)

c. Kepala Kantor Pertanahan ditunjuk selaku PPAT Khusus

Pasal 12 ayat (1) Daerah Kerja PPAT adalah satu wilayah kerja Kantor Pertanahan Kabupaten/Kotamadya, dan juga diatur dalam pasal 13 ayat (1) dan ayat (2) PP No. 37/1998 adalah sebagai berikut ini:

1. Pasal 13 ayat (1): Apabila suatu wilayah Kabupaten/Kotamadya dipecah menjadi dua atau lebih wilayah Kabupaten/

\footnotetext{
${ }^{14}$ Boedi Harsono, Op. Cit, hal 479
}

Kotamadya, maka dalam waktu 1 (satu) tahun sejak diundangkannya undangundang tentang pembentukan Kabupaten/Kotamadya sebagai daerah kerja dengan ketentuan apabila pemilihan tersebut tidak dilakukan pada waktunya, maka mulai1 (satu) tahun sejak diundangkannya undang-undang pembentukan kabupaten/kotamadya Daerah Tingkat II baru tersebut daerah kerja PPAT yang bersangkutan hanya meliputi wilayah Kabupaten/ Kotamadya letak kantor PPAT yang bersangkutan,

2. Pasal 13 ayat (2); Pemilihan Daerah Kerja sebagaimana dimaksud pada ayat (1) berlaku dengan sendrinya mulai 1 (satu) sejak diundangkannya di undangundang pembentukan Kabupaten/Kotamadya Daerah Tingkat I yang baru. Serta diatur juga dalam pasal 14 ayat (1) dan ayat (2) PP No. 37/1998 tentang Peraturan jabatan Pembuat Akta Tanah.

1. Pasal 14 ayat (1): Formasi ditetapkan oleh Menteri Agraria/ Badan Pertanahan Nasional

2. Pasal 14 ayat (2): apabila formasi PPAT untuk satu daerah kerja PPAT sudah terpenuhi maka Menteri Agraria/ Badan Pertanahan Nasional menetapkan wilayah tersebut tertututp pengangkatan PPAT, maksud dari pasal 14 ayat (2) 
tersebut diatas adalah: dengan adanya penetapan formasi ada suatu daerah Kabipaten/Wilayah Daerah Tingkat II akan dapat dibatasi penempatan PPAT pada suatu daerah, sehingga daerah lain yang masih tersedia lowongannya dapat diisi, maka tujuan penempatan pemerataan PPAT dapat tercapai.

\section{Fungsi dan Kewenangan Pejabat}

\section{Pembuat Akta Tanah ( PPAT)}

Berdasarkan ketentuan dalam pasal

2 Peraturan Pemerintah Nomor 37

Tahun1998 tentang peraturan jabatan

Pejabat Pembuat Akta Tanah (PPAT), tugas pokok dan kewajiban pejabat pembuat akta tanah (PPAT) adalah sebagai berikut: ${ }^{15}$

1) PPAT

bertugas

pokok melaksanakansebagaian kegiatan pendaftaran tanah dengan membuat akta sebagai bukti telah dilakukannya perbuatan hukum tertentu mengenai hak atas tanah danhak milik atas satuan rumah susun, yang akan dijadikan dasar sebagai perubahan data pendaftaran tanah yang diakibatkan oleh perbuatan hukum itu,

${ }^{15}$ Pasal 1 ayat (4) Undang-undang Nomor 4 Tahun 1996 tentang Hak Tanggungan Atas Tanah berserta benda-benda yang berkatan dengan tanah, dan pasal 1 ayat(1) Peraturan Pemerintah Nomor 37 Tahun 1998 tentang Peraturan Jabata PPAT
2) Perbuatan hukum sebagaiman dimaksud ayat (1) adalah sebagai berikut:

a. Jual-beli;

b. Tukar-menukar;

c. Hibah;

d. Pemasukan ke dalam perusahaan (inbreng);

e. Pembagian hak bersama;

f. Pemberian hak guna bangunan/ Hak Pakai atas tanah Hak Milik;

g. Pemberian Hak Tanggungan;

h. Pemberian Kuasa membebankan Hak Tanggungan.

Penyetoran Pajak BPHTB itu merupakan kewenangan dari wajib pajak bukan Notaris, akan tetapi Notaris dapat menyetorkan pajak BPHTB sebagai orang yang dipercaya oleh nasabahnya. Notaris sebagai pejabat secara tidak langsung mengurangi beban tugas fiskus untuk mebantu menghitung besarnya pajak BPHTB yang terutang, serta dapat pula membantu wajib pajak untuk menghitung dan menyetorkan pajak yang terutang. ${ }^{16}$

\section{Sanksi Perpajakan}

${ }^{16}$ Agustina Lusiana Elisabet Lumban Batu ,Analisis Hukum atas perbuatan oknum notaris yang menerima penitipan pembayaran Bea Perolehan Hak Atas Tanah dan BAngunan (BPHTB) (Studi Putusan Pengadilan Negeri Medan Np.2601/Pid.B/2003/PN-Mdn).Tesis Magister Kenotariatan USU, Fakultas Hukum USU, 2015, hal 4 
Sanksi dalam perpajakan menjadi penting karena Pemerintah Indonesia memilih menerapkan Self Assessment system dalam pelaksanaan pemungutan pajak. Berdasarkan sistem ini, wajib pajak diberikan kepercayaan untuk menyetor, dan melaporkan pajaknya sendiri.Untuk dapat menjalankannya dengan baik, maka setiap wajib pajak berhak memerlukan pengetahuan pajak, baik dari segi peraturan maupun teknis administrasinya agar pelaksanaannya dapat tertib dan sesuai dengan target yang diharapkan.

Ada 2 (dua) jenis sanksi pajak dalam undang-undang pajak, oleh wajib pajak: 1. Sanksi Pidana dan Sanksi Administrasi

\section{Sanksi Perpajakan atas PPAT yang tidak melaksanakan ketentuan terhadap akta yang ditandatangani tapi BPHTB Belum Dibayar}

a. PPAT Sementara

Sanksi perpajakan atas PPAT Sementara yang tidak melaksanakan ketentuan terhadap Akta yang ditandatangani tapi belum di bayar BPHTBnya tidak ada peraturan perundang-undangan yang mengatur. Adapun PPAT Sementara yang dimaksud dalam hal ini adalah Camat. Camat atau Kepala Desa untuk melayani pembuatan akta di daerah yang belum cukup terdapat pejabat pembuat akta tanah sebagai pejabat pembuat akta tanah sementara

\section{b. PPAT Khusus}

Sanksi perpajakan atas PPAT Khusus yang tidak melaksanakan ketentuan terhadap Akta yang ditandatangani tapi belum dibayar BPHTB-nya diatur Peraturan Perundangundangan.

c. PPAT/ Notaris

Sanksi perpajakan atas PPAT/Notaris yang tidak melaksanakan ketentuan terhadap akta yang ditandatangani tapi belum dibayar BPHTBnya diatur Pasal 27 Ayat (1) Peraturan Daerah Kota Medan Nomor 1 Tahun 2011 tentang Bea Perolehan Hak Atas Tanah dan Bangunan yang berbunyi “ Pejabat Pembuat Akta Tanah/ Notaris dan Kepala Kantor yang membidangi pelayanan lelang Negara yang melanggar ketentuan sebagaimana dimaksud dalam pasal 25 ayat (1) dan ayat (2) dikenakan sanksi administratif berupa denda sebesar Rp. 7.500.000,- (tujuh juta lima ratus ribu rupiah) untuk setiap pelanggaran.

\section{E. KESIMPULAN}

Berdasarkan uraian-uraian yang telah dijelaskan maka penulis dapat menyimpulkan sebagai berikut: 
1. Pengaturan hukum tentang Bea Perolehan Hak Atas Tanah dan Bangunan menurut Undang-undang Nomor 28 Tahun 2009 Tentang Pajak Daerah dan Retribusi Daerah. Dan Peraturan Daerah (Perda) Kota Medan Nomor 1 Tahun 2011 Tentang Bea Perolehan Hak Atas Tanah dannBangunan:

a. Objek Pajak Bea Perolehan Hak Atas Tanah dan Bangunan adalah perolehan hak atas tanah dan bangunan.

b. Subjek Bea Perolehan Hak Atas Tanah dan Bangunan adalah Orang Pribadi atau Badan yang memperoleh hak atas tanah dan atau bangunan,

c. Besarnya Nilai Perolehan Objek Pajak Tidak Kena Pajak ditetapkan paling rendah sebesar Rp. 60.000.000,- (enam puluh juta rupiah),

d. Tarif Bea Perolehan Hak Atas Tanah dan Bangunan ditetapkan paling tinggi sebesar 5\% (lima persen)

e. Sistem pemungutan pajak Bea Perolehan Hak Atas dan Bangunan yang dikenal adalah self assessment system setiap wajib pajak wajib membayar pajak yang terutang berdasarkan surat ketetapan pajak atau dibayar sendiri oleh wajib pajak berdasarkan peraturan perundang-undangan,

f. Pejabat pembuat akta tanah/notaris hanya dapat menandatangani akta pemindahan hak atas tanah dan/atau bangunan setelah wajib pajak bukti pembayaran pajak,

g. Sanksi administrasi kepada pejabat pembuat akta tanah/notaris apabila menandatangani akta pemindahan hak atas tanah dan/atau bangunan dikenakan denda sebesar Rp. 7.500.000,-(tujuh juta lima ratus ribu rupiah) untuk setiap pelanggaran.

2. Pengaturan hukum tentang Pemungutan Bea Perolehan Hak Atas Tanah dan Bangunan adalah Peraturan Walikota Medan Nomor 24 Tahun 2011 tentang Sistem dan Prosedur Pemungutan Perolehan Hak Atas Tanah dan Bangunan Verifikasi dan validasi merupakan prosedur penelitian Surat Setoran Pajak Daerah BPHTB (SSPD BPHTB) terkait kelengkapan dokumen dan kebenaran data objek pajak yang tercantum dalam SSPD BPHTB. Prosedur ini dilakukan setelah wajib pajak melakukan pembayaran BPHTB terutang. Jika semua kelengkapan dan kesesuaian data objek pajak, terpenuhi maka fungsi pelayanan akan menandatangani SSPD BPHTB tersebut,

3. Menurut undang undang nomor 28 Tahun 2009 tentang pajak daerah dan retribusi daerah bahwa notaris hanya dapat menandatangani akta pemindahan hak seteleah wajib 
pajak menyerahkan bukti belum memenuhi prinsip keadilan, pembayaran pajak BPHTB yaitu Karena dalam pemberian sanksi dalam SSPD, . yang berbeda antara PPAT/Notaris,

4. Untuk pemenuhan prinsip keadilan PPAT Sementara, dan PPAT Khusus dalam pemberian sanksi bagi PPAT atas penandatanganan akta jual beli 


\section{DAFTAR PUSTAKA}

\section{BUKU}

Ali Chidir (1993), Hukum Pajak Elementer, Eresco, Bandung,

Anggraini Sary Puspita (2010), Sitem Pemungutan Bea Perolehan Hak Atas Tanah dan Bangunan (studi Kasus di Kota Medan,), Tesis Magister Kenotariatan USU, Fakultas Hukum USU.

Asofa Burhan (2010), Metode Penelitian Hukum, Rineka Cipta, Jakarta, H.R. Otje Anton F Susanto dan Salman, S (2005), Teori Hukum, Rafika Aditama, Bandung,

Bohari (1993), Pengatar Hukum Pajak, PT. Raja Grafindo Persada, Jakarta,

Brian Brix,(2011) Radbruch's Formula and Conceptual Analysis, The American Jurnal Of Jurisprudenci, Volume 56,

Brotodiharjo Santoso (1986), Pengantar Ilmu Hukum Pajak, Bandung, Ersesco,

C.S.T. Kansil, (1986), Pengantar Ilmu Hukum, Balai Pustaka, Jakarta,

Erika Jenri Halasan P (2012), TInjauan Yuridis Terhadap Kewajiban Verifikasi Bea Perolehan Hak Atas Tanah dan BAngunan di Kota Pekan Baru, Tesis Magister Kenotariatan USU, Fakultas Hukum USU, hal 42

Fuady Munir, (2007) Sosiologi Hukum Kontemporer, Interaksi Kekuasaan Hukum , dan Masyarakat, Bandung, Citra Aditya Bakti

Kalo Syafruddin (2004), Pengadaan Tanah Bagi Pembangunan Untuk Kepentingan Umum, Pustaka Bangsa Press, Jakarta.

Kurniawan, P., \& Purwanto, A, (2004) Pajak Daerah dan Retribusi Daerah di Indonesia, Bayumedia Publishing, Malang,

Lubis M. Solly , (1994), Filsafat Ilmu dan Penelitian, Mandar Maju, Bandung,

Marbun Dameria Novita, Analisis Hukum Peranan Pejabat Pembuat Akta Tanah dalam Pemungutan BPHTB dalam Transaksi Jual Beli Tanah dan/atau Bangunan di Kabupaten Humbang Hasundutan. Tesis Magister Kenotariatan Pascasarjana Universitas Sumatera Utara. Fakultas Hukum Universitas Sumatera Utara. 2018 Mardiasmo ( 2001), Perpajakan Edisi Revisi 2001, Yogyakarta, Andi Offest, 
Mardiasmo (2000), Perpajakan, Andi,

Mardiasmo. (2009), Perpajakan Edisi Revisi, Yogyakarta: Andi Offset

Melinda Yogia S. (1982), Capita Selecta Perpajakan di Indonesia, Armico, Bandung,

Moleong, L.J. (2000), Metodologi Penelitian Kuantitatif, Bandung, PT. Remaja Rosda Karya

Nasution Lira Apriani Sari (2012) Analisis Yuridis Pemungutan Bea Perolehan Hak Atas Tanah dan Bangunan atas Peralihan Hak ibah Wasiat (Studi di Kota Medan), Tesis Magister Kenotariatan USU, Fakultas hukum USU, 2012

P. Halasan Jenri Erika, Tinjauan Yuridis Terhadap Kewajiban Verifikasi Bea Perolehan Hak Atas Tanah dan Bangunan (BPHTB) atas Peralihan Hak Atas Tanah dan Bangunan di Kota Pekanbaru. Tesis Magister Kenotariatan Pascasarjana Universitas Sumatera Utara. Fakultas Hukum Universitas Sumatera Utara.2012

Parlindungan A.P (1989) , Bunga Rampai Hukum Agraria serta Landreform, Bandung,

Penelitian Hukum Normatif, Banyu Media, Malang,

Perangin Effendi (1994), Hukum Agraria di Indonesia, Jakarta, Raja Grafindo Persada,

Priantara ,D,(2000) Pemeriksaan dan Penyidikan Pajak, Djambatan, Jakarta,

Purba Hasim (2006), Suatu Pedoman Memahami Ilmu Hukum, Cahaya Ilmu, Medan, R.Sanotoso Brotodihardjo,(1993)Pengantar Ilmu Hukum Pajak, PT. Eresco Bandung.

Rosana Ellya , (2014), Kepatuhan Hukum Sebagai Wujud Kesadaran Hukum Masyarakat, Jurnal Tapis Vol.10 No.1 Januari-Juni

Ryanto Fith (2015), Analisis Hukum Sistem Pemungutan Bea Perolehan Hak Atas Tanah dan Bangunan di Kabupaten Agam, Tesis Magister Kenotariatan USU, Fakultas Hukum USU,

Simbolon Tua Ada (2014), Peranan Pejabat Pembuat Akta Tanah dalam Pembayaran Pajak Bea Perolehan Hak Atas Tanah dan Bangunan (BPHTB) atas Transaksi Tanah dan Bangunan di Kabupaten Samosir, Tesis Magister Universitas Sumatera Utara. Fakultas Hukum Universitas Sumatera Utara.

Siti Kurnia Rahayu,(2010) Perpajakan Indonesia Konsep dan Aspek Formal, Graha Ilmu, Yogyakarta, 
Sitompul Sri Yumeinar (2012), Sanksi Administratif terhadap PPAT/Notaris atas Kelalaian Pengawasan Pembayaran BPHTB dalam Pembuatan Akta Peralihan Hak Atas Tanah dan Bangunan, Tesis Magister Kenotariatan USU, Fakultas Hukum USU, Soemitro Rochmat (1991), Pajak Ditinjau Dari Segi Hukum, Eresco, Bandung

Soemitro Rochmat S (1990), Dasar-dasar Hukum Pajak dan Pajak Pendapatan, Eresco, Bandung,

\section{Peraturan Perundang Undangan}

Undang undang nomor 28 Tahun 2009 Tentang Pajak Daerah dan Retribusi Daerah

Peraturan Daerah Kota Medan Nomor 1 Tahun 2011 Tentang Bea Perolehan Hak Atas Tanah dan Bangunan

Peraturan Pemerintah Nomor 37 Tahun 1998 sebagaimana telah diubah menjadi Peraturan Pemerintah Nomor 24 Tahun 2016 tentang Pejabat Pembuat Akta Tanah (PPAT

Peraturan Walikota Medan Nomor 24 Tahun 2011 tentang Sistem dan Prosedur Pemungutan Bea Peroleh Bangunan Hak Atas tanah dan/ Atau Bangunan

Undang-undang Nomor 4 Tahun 1996 tentang Hak Tanggungan Atas Tanah berserta bendabenda yang berkaitan dengan tanah,

Peraturan Pemerintah Nomor 24 tahun 1997 tentang pendaftaran tanah, peralihan hak atas tanah dan satuan rumah susun.

Undang undang Ketentuan Umum dan Tata Cara Perpajakan Nomor 28 Tahun 2007 dan Nomor 16 Tahun 2009 tentang Sanksi administrasi.

\section{INTERNET}

Informasi Pendidikan, “Penelitian Deskriptif Kualitatif”,www.informasi-pendidikan.com, diakses dari http://www.informasi-pendidikan.com/2013/08/penelitian-deskriptifkualitatif,html.n, pada tanggal 09 Februari 2019, pukul 15.34 WIB

Jurnal hukum Faisal Akbar Nasution, Daerah Pasca Reformasi. Vol. 18. Kebijakan Perimbangan Keuangan 2011

antara Pemerintah Pusat dan 
Bastari,Sistem Pemungutan BPHTB dalam Daerahdi Medan pada tanggal 29 Seminar BPHTB Pasca Pengalihan Januari 2013

Dari PajakPusat Menjadi Pajak 